\title{
Long-term Variability of Aerosol Optical Properties at Mauna Loa
}

\author{
Jong-Uk Park ${ }^{1}$, Sang-Woo Kim ${ }^{1}{ }^{*}$, Patrick J. Sheridan ${ }^{2}$, Alastair Williams ${ }^{3}$, Scott D. Chambers ${ }^{3}$ \\ ${ }^{1}$ School of Earth and Environmental Sciences, Seoul National University, Seoul 08826, Korea \\ ${ }^{2}$ NOAA, Global Monitoring Laboratory, Boulder, CO 80305, USA \\ ${ }^{3}$ Australian Nuclear Science and Technology Organisation (ANSTO), Lucas Heights, NSW 2234, Australia
}

\begin{abstract}
We investigated the variability of the aerosol scattering $\left(\sigma_{\mathrm{sp}} ; 1974-2015\right)$ and absorption $\left(\sigma_{\mathrm{ap}} ; 2000-2015\right)$ coefficients at the Mauna Loa Observatory using surface in situ measurements. Although $\sigma_{\mathrm{sp}}$ decreased during the morning $\left(1.85 \pm 3.43 \mathrm{Mm}^{-1}\right.$ at $550 \mathrm{~nm}, 8-11$ local standard time [LST]), it increased during the afternoon $\left(3.72 \pm 7.63 \mathrm{Mm}^{-1}\right.$ at $\left.550 \mathrm{~nm}, 14-17 \mathrm{LST}\right) \mathrm{due}$ to the development of thermally induced boundary layer winds. No distinct diurnal variation was observed in $\sigma_{\text {ap. }}$ The obvious increase in $\sigma_{\mathrm{sp}}$ and $\sigma_{\mathrm{ap}}$ during the spring under free troposphere conditions (8-11 LST) is attributed to long-rangetransported aerosols from Asia, especially dust and pollution aerosols from Northeast Asia and biomass burning aerosols from Southeast Asia. Accordingly, $\sigma_{\text {sp }}$ increased from 1974 till 2015 (at $1.89 \%$ year $^{-1}$ ), whereas no significant trend was noted for either $\sigma_{\mathrm{sp}}$ or $\sigma_{\mathrm{ap}}$ from 2000 till 2015. An increasing trend for $\sigma_{\mathrm{sp}}$ prevailed in air masses originating in Northeast Asia $\left(+0.51 \mathrm{Mm}^{-1}\right.$ decade $\left.^{-1}\right)$.
\end{abstract}

Keywords: Aerosol in situ measurement; Aerosol scattering coefficient; Aerosol absorption coefficient; Mauna Loa.

\section{INTRODUCTION}

Optical and radiative properties of atmospheric aerosols depend on their chemical compositions, shapes, and particle size distributions (Haywood and Ramaswamy, 1998; Delene and Ogren, 2002; Jacobson, 2002). These properties exhibit high spatial and temporal variations because of the relatively short lifetime and uneven geographical distribution related to emissions, chemical processes in the atmosphere, and weather patterns (Delene and Ogren, 2002; Andrews et al., 2011; Boucher et al., 2013; Collaud Coen et al., 2013; Park et al., 2019). Even though the space-based and ground-based remote sensing measurements allow the quantification of aerosol optical properties (AOPs) at increased spatiotemporal resolutions, they still have limitations retrieving sufficiently accurate AOPs other than the aerosol optical depth (AOD). Surface in situ measurements of AOPs play a crucial role (Hansen et al., 1995) in the reduction of the uncertainty by providing essential information in a more direct way (Andrews et al., 2011; Park et al., 2019).

Continuous, long-term measurements of aerosols, especially in the free troposphere (FT), are needed to understand their long-range transport, trends, and global or regional climate

\footnotetext{
* Corresponding author.

Tel.: +82-2-880-6716; Fax: +82-2-883-4972

E-mail address: sangwookim@snu.ac.kr
}

effects (Laj et al., 2009). Aerosols in the FT are spatially more representative than observations within the boundary layer because the lifetime of atmospheric aerosols lifted into the FT can be extended up to several weeks (Kent et al., 1998), and they can travel much faster and further due to the strong prevailing winds (McKendry et al., 2001; Wandinger et al., 2002; Liu et al., 2003; Mattis et al., 2008; Uno et al., 2009).

Measurements of AOPs at the Mauna Loa Observatory (MLO; $19.54^{\circ} \mathrm{N}, 155.58^{\circ} \mathrm{W}, 3397 \mathrm{~m}$ above mean sea level) were conducted by the National Oceanic and Atmospheric Administration (NOAA) Earth System Research Laboratory (ESRL) Global Monitoring Division (GMD), as part of the NOAA Federated Aerosol Network (NFAN; Andrews et al., 2019). The MLO has been considered as an ideal location to monitor the FT background aerosol properties because of its geographical location (Lee et al., 1994; Ryan et al., 1997; Perry et al., 1999; Andrews et al., 2019). However, several model simulations and in situ measurements revealed that MLO is affected by both long-range-transported (LRT) aerosols, and aerosols entrained from the local planetary boundary layer (PBL; Mendonca, 1969; Shaw, 1980; Bodhaine et al., 1981; Miller, 1981; Darzi et al., 1982; Merrill et al., 1989; Harris et al., 1990; Bodhaine et al., 1995; 1996; Ryan, 1997; Perry et al., 1999; Takemura et al., 2002; Eck et al., 2005; Sharma and Barnes, 2016). To investigate the FT background of aerosol characteristics at MLO, it is necessary to deconvolute the influences from LRT and the local PBL.

In this study, we investigate the aerosol scattering and 
absorption properties at MLO from surface in situ measurements. We explore the diurnal variation of AOPs and determine the FT conditions (i.e., by excluding local influences) using Rn-222 concentrations. Seasonal variations and the trend of AOPs are then analyzed according to airmass origin.

\section{METHODS}

Hourly mean aerosol scattering coefficient $\left(\sigma_{\mathrm{sp}}\right)$ measured for total suspended particles without size cuts (January 1974-April 2000), and for sub-10 $\mu \mathrm{m}$ particles (April 2000 December 2015) with nephelometers at MLO, were used in this study. This is because the aerosol impactor system, which switches every 6 minutes for measuring sub-10 $\mu \mathrm{m}$ and submicron particles, was installed in April 2000 (Sheridan et al., 2001; Delene and Ogren, 2002). The aerosol absorption coefficient $\left(\sigma_{\mathrm{ap}}\right)$ for sub-10 $\mu \mathrm{m}$ particles measured with filter-based absorption photometers (i.e., particle soot absorption photometer [PSAP] and continuous light absorption photometer [CLAP]) from April 2000 were analyzed. Both $\sigma_{\mathrm{sp}}$ and $\sigma_{\mathrm{ap}}$ were measured under low relative humidity (RH; $<40 \%$; Sheridan et al., 2001) and were corrected to standard temperature and pressure (STP; i.e., $273.15 \mathrm{~K}$ and 1013.25 $\mathrm{hPa}$ ). All $\sigma_{\mathrm{sp}}$ and $\sigma_{\mathrm{ap}}$ data (Level 2) were downloaded from NOAA/ESRL/GMD (ftp://ftp.cmdl.noaa.gov/aerosol/mlo/). Detailed descriptions of instruments, data periods, data corrections, and associated uncertainties are listed in Table 1.

Intensive AOPs, such as single-scattering albedo (SSA), scattering Ångström exponent (SÅE), and absorption Ångström exponent (Å̊E), were derived from $\sigma_{\mathrm{sp}}$ and $\sigma_{\mathrm{ap}}$ to examine more detailed aerosol radiative and physical characteristics (Delene and Ogren, 2002). In this study, SSA was calculated at $550 \mathrm{~nm}$ (Eq. (1)). Herein, $\sigma_{\text {ap }}$ was adjusted to a wavelength $(\lambda)$ of $550 \mathrm{~nm}$ by using the $1 / \lambda$ dependence of aerosol light absorption (van der Hulst, 1957; Bergstrom et al., 2002).

Single Scattering Albedo $(550 \mathrm{~nm})=$

$$
\frac{\sigma_{s p}(550 \mathrm{~nm})}{\sigma_{s p}(550 \mathrm{~nm})+\sigma_{a p}(550 \mathrm{~nm})}
$$

$\mathrm{S} \AA \mathrm{E}$ was calculated from $\sigma_{\mathrm{sp}}$ at 450 and $700 \mathrm{~nm}$ wavelengths:

$$
\text { Scattering Ångström Exponent }=\frac{\ln \left(\frac{\sigma_{s p}(450 \mathrm{~nm})}{\sigma_{s p}(700 \mathrm{~nm})}\right)}{\ln \left(\frac{450 \mathrm{~nm}}{700 \mathrm{~nm}}\right)}
$$

These intensive AOPs were calculated only if $\sigma_{\mathrm{sp}} \geq 1 \mathrm{Mm}^{-1}$ and $\sigma_{\mathrm{ap}} \geq 0.1 \mathrm{Mm}^{-1}$ to avoid substantial relative uncertainties which were induced when $\sigma_{\mathrm{sp}}\left(\sigma_{\mathrm{ap}}\right)$ was close to the detection limit.

Hourly mean $\mathrm{Rn}-222$ volume concentrations $\left(\mathrm{mBq} \mathrm{m}^{-3}\right)$ recorded at MLO since 2003 enabled us to identify the time

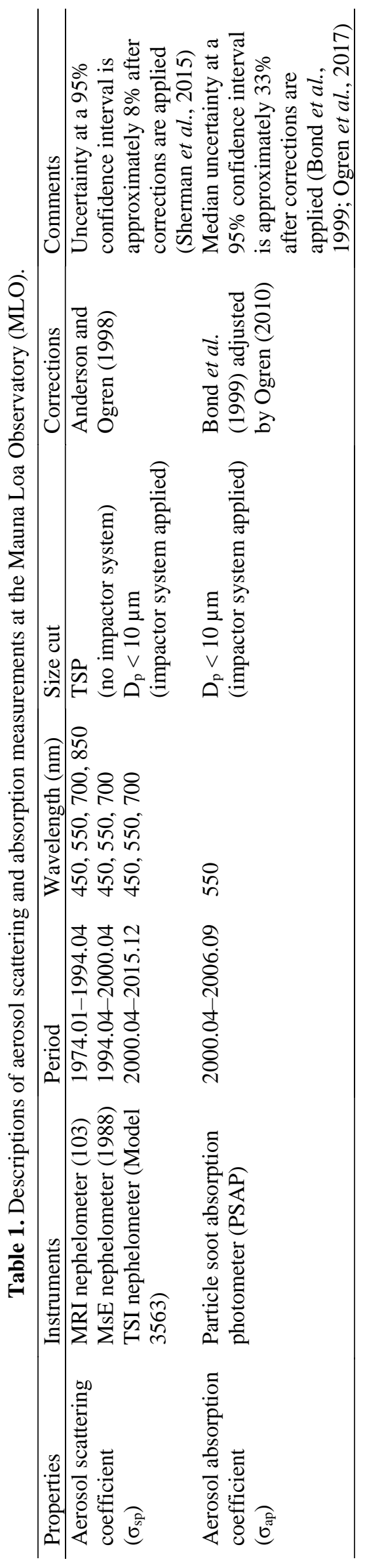


of the day when the observatory is least perturbed by local influences. Rn-222 is a naturally occurring radioactive gas with a relatively short half-life (3.82 days; Turekian et al., 1977). Additionally, the main influx of Rn-222 to the atmosphere is attributed to the land surface, which is $2-3$ orders higher than the oceanic flux (Schery and Huang, 2004). Rn-222 remains in a gaseous state in the atmosphere and is known to be removed solely by its radioactive decay due to its hydrophobicity and nature as a noble gas (Turekian et al., 1977). Therefore, Rn-222 can be considered as an ideal tracer for identifying terrestrial (soil) influences (Chambers et al., 2011, 2013, 2016).

Airmass backward trajectories (BTs) over 10-day periods $(240 \mathrm{~h})$, calculated using the NOAA Air Resources Laboratory's Hybrid Single-Particle Lagrangian Integrated Trajectory (HYSPLIT) model (v4.0; Draxler and Hess, 1998) from the location of MLO, were used to identify the source regions of aerosols at the MLO in FT conditions. National Centers for Environmental Prediction (NCEP)/National Center for Atmospheric Research (NCAR) reanalysis data (.gbl) was utilized as an input meteorological field (e.g., horizontal and vertical winds; Kalnay et al., 1996). Each BT was constructed every hour and was paired with hourly mean AOPs to identify the relationship between the AOPs and the origin of the airmass.

The trends of $\sigma_{\mathrm{sp}}$ and $\sigma_{\mathrm{ap}}$ with their significance over the study period were examined with the Theil-Sen slope method and the Mann-Kendall (MK) test. The Theil-Sen method calculates the slope of the possible trend with a nonparametric approach. It uses the median value of the calculated slopes from all possible pairs of data synched with time information. The Mann-Kendall test is a nonparametric statistical test which is well suited to identify small but monotonic trends. These are typically used because of their insensitivity to missing values and outliers in a time series (Mann, 1945; Kendall, 1975; Gilbert, 1987; Collaud Coen et al., 2013).

\section{RESULTS AND DISCUSSION}

The median value of $\sigma_{\mathrm{sp}}$ at $550 \mathrm{~nm}$ based on measurements collected during a 42-year period (1974-2015) was $0.94 \mathrm{Mm}^{-1}$, and the median value $\sigma_{\mathrm{ap}}$ at $550 \mathrm{~nm}$ during the period of 2000-2015 was $0.13 \mathrm{Mm}^{-1}$. The overall mean values of $\sigma_{\mathrm{sp}}$ and $\sigma_{\text {ap }}$ at $550 \mathrm{~nm}$ were $2.47 \mathrm{Mm}^{-1}$ and $0.28 \mathrm{Mm}^{-1}$, respectively, with relatively large standard deviations $\left(4.99 \mathrm{Mm}^{-1}\right.$ and $0.45 \mathrm{Mm}^{-1}$ ). This implies that MLO is operating under the pristine conditions most of the time, but it is intermittently affected by highly aerosol-loaded airmasses.

\section{Diurnal Variation of AOPs and Determination of FT Condition}

Fig. 1 shows the diurnal variation of in situ AOPs and Rn222 concentrations at MLO. $\sigma_{\mathrm{sp}}$ exhibited a distinct diurnal variation, with increases in the afternoon hours (14-17 LST) and decreases during the morning hours (8-11 LST). High aerosol loadings, as indicated by $\sigma_{\mathrm{sp}}$, during the afternoon hours, can be explained by the prevailing thermally induced (anabatic) winds up the flanks of Mauna Loa Mountain. Elevated Rn-222 concentration-which represents how recently the air mass was in contact with the land surface (Chambers et al., 2011, 2013) - is usually associated with the upslope wind which develops along the ridge of the mountain during the afternoon hours, whereas the upslope wind is also responsible for the influx of the PBL aerosols to MLO (Ryan et al., 1997). Meanwhile, no significant diurnal variation was observed in $\sigma_{\mathrm{ap}}$. The transport of scattering-dominant maritime aerosols from PBL to MLO by the aforementioned upslope wind is thought to be the reason for the elevated SSA in the afternoon, since MLO is located on the Big Island of Hawaii, where no particular industrial activities are held (DBEDT, 2019).

Interestingly, Rn-222 concentrations typically decreased between approximately 8 and 11 LST, which is a transition period between dominant, thermally driven katabatic (downslope) and anabatic (upslope) winds (Ryan et al., 1997; Chambers et al., 2013). In this study, we designated these hours of the day (8-11 LST) as Least Locally Influenced (LLI) hours to examine AOPs in FT conditions. A summary of the values of $\sigma_{\mathrm{sp}}$ and $\sigma_{\mathrm{ap}}$ over 24-h and LLI-h periods is listed in Table 2 . Both daily mean and median $\sigma_{\mathrm{sp}}$ values were approximately $34 \%$ and $32 \%$ higher than those of the LLI hours, respectively, whereas the $\sigma_{a p}$ values corresponding to the 24-h and LLI-h periods were not significantly different. Compared to the daily mean, the slightly lower SSA $(0.87 \pm 0.12)$ and higher SÅE $(1.35 \pm$ 1.24) values during the LLI h (see the white dashed boxes in Fig. 1(b)) suggest that the aerosols in FT conditions are more absorbing and slightly larger.

\section{Seasonal Variation of FT Aerosols \\ Air Mass Origins}

Fig. 2 shows the aerosol optical depth $(550 \mathrm{~nm})$ from 13-year Moderate Resolution Imaging Spectroradiometer (MODIS) measurements with selected air mass source regions, and the monthly variation of percentages of air mass origins estimated based on BTs constructed over 10-day periods. The largest fraction of airmasses that reached MLO was from the Pacific Ocean (PO; 43.5\%). Approximately $24.7 \%$ and $13.1 \%$ of airmasses originated from Northeast Asia (NE Asia) and Southeast Asia (SE Asia), respectively, the largest emission sources of natural (dust, biomass burning) and anthropogenic aerosols, as indicated by the MODIS-derived AOD. Several studies reported that aerosol properties at MLO were largely affected by Asian outflow (Bodhaine et al., 1981; Bodhaine, 1995; 1996; Perry et al., 1999; Eck et al., 2005). It is noteworthy that the AOPs at MLO were not much influenced by airmasses that originated from other regions (18.7\%; Central America, continents in North Pacific Ocean, North America and continents in the Southern Hemisphere).

MLO is more frequently influenced by Asian airmasses (> 50\%) from December to April due to the southward shift of the Intertropical Convergence Zone (ITCZ; HendersonSellers and Robinson, 1991; Schneider et al., 2014). By contrast, airmasses from Asia substantially decrease during June-September due to weakening FT westerlies along the Hawaiian Islands by the northward shift of the ITCZ. Instead, airmasses from North and Central America increase, even 
(a)

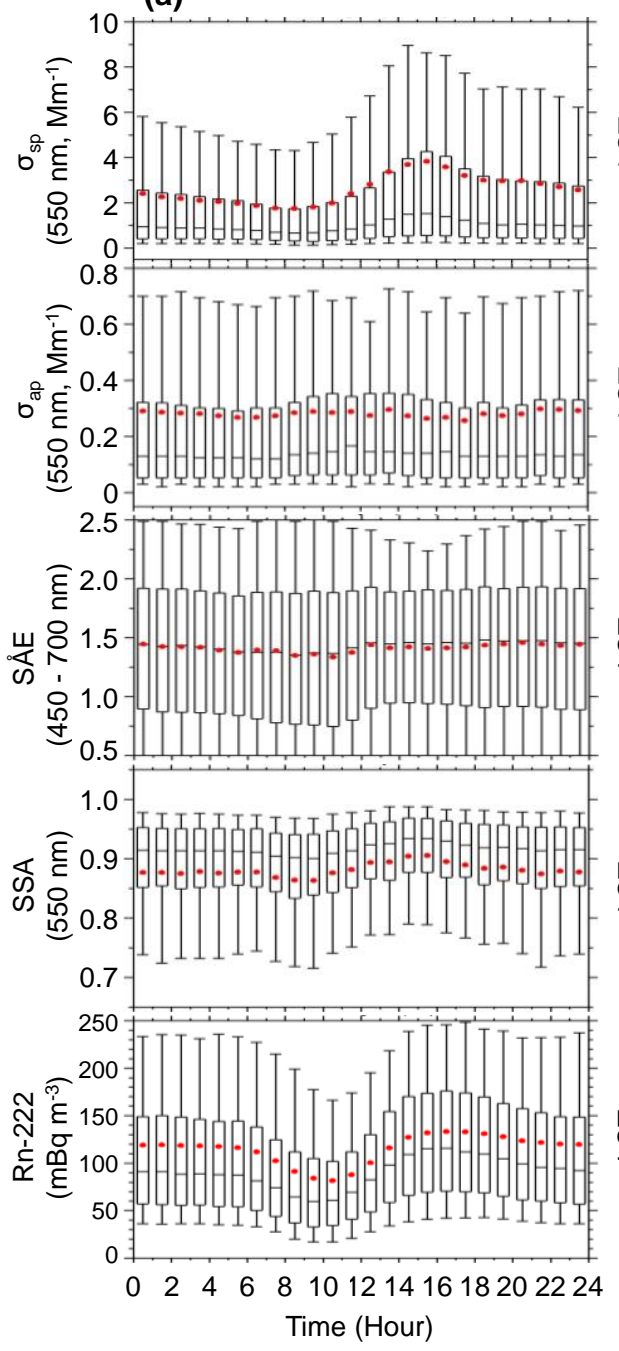

(b)

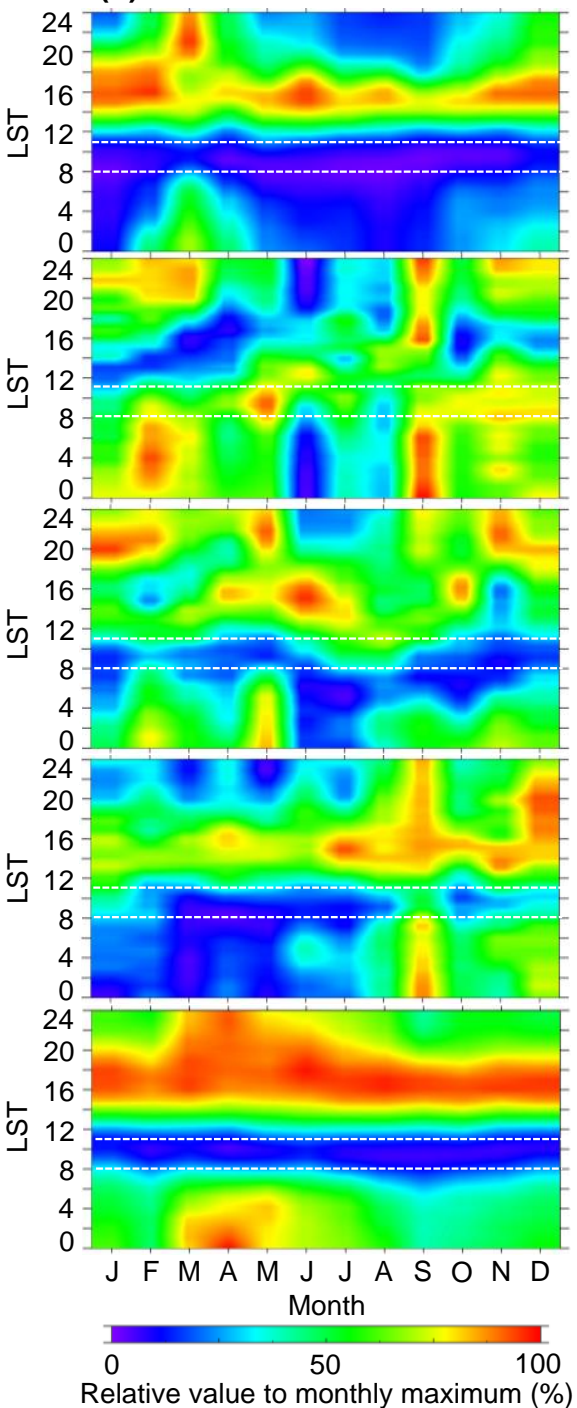

Fig. 1. Diurnal variation of the aerosol optical properties (AOPs; $\sigma_{\mathrm{sp}}, \sigma_{\mathrm{ap}}$, SÅE and SSA) and ${ }^{222} \mathrm{Rn}$ concentration at the Mauna Loa Observatory (MLO). (a) Box-and-whisker plot, whereby the whiskers represent the $10^{\text {th }}$ and $90^{\text {th }}$ percentiles, and the horizontal lines in boxes represent the $25^{\text {th }}, 50^{\text {th }}$, and $75^{\text {th }}$ percentiles of the hourly values. The mean values are denoted with red dots. (b) Annual cycle of the diurnal variability of AOPs. Variables are normalized with the maximum hourly average value of the month. The least locally influenced (LLI) period (8-11 LST) is denoted by the white dotted line.

Table 2. Comparison of aerosol scattering $\left(\sigma_{\mathrm{sp}}\right)$ and absorption $\left(\sigma_{\mathrm{ap}}\right)$ coefficients over 24-h and least locally influenced (LLI)-h periods.

\begin{tabular}{llll}
\hline & & $24 \mathrm{~h}(0-24 \mathrm{LST})^{a}$ & LLI h $(8-11 \mathrm{LST})^{a}$ \\
\hline Aerosol scattering coefficient & Mean & 2.47 & 1.85 \\
$\left(550 \mathrm{~nm}, \mathrm{Mm}^{-1}\right)$ & Standard deviation & 4.99 & 3.43 \\
& MAD $^{b}$ from mean & 2.48 & 1.87 \\
& Median & 0.94 & 0.71 \\
& MAD from median & 2.03 & 1.51 \\
Aerosol absorption coefficient & Mean & 0.28 & 0.29 \\
$\left(550 \mathrm{~nm}, \mathrm{Mm}^{-1}\right)$ & Standard deviation & 0.45 & 0.42 \\
& MAD from mean & 0.26 & 0.26 \\
& Median & 0.13 & 0.14 \\
\hline
\end{tabular}

${ }^{a}$ Times are in Hawaiian local standard time (LST = Coordinated Universal Time [UTC] - $10 \mathrm{~h}$ ).

${ }^{b}$ MAD: Mean absolute deviation. 


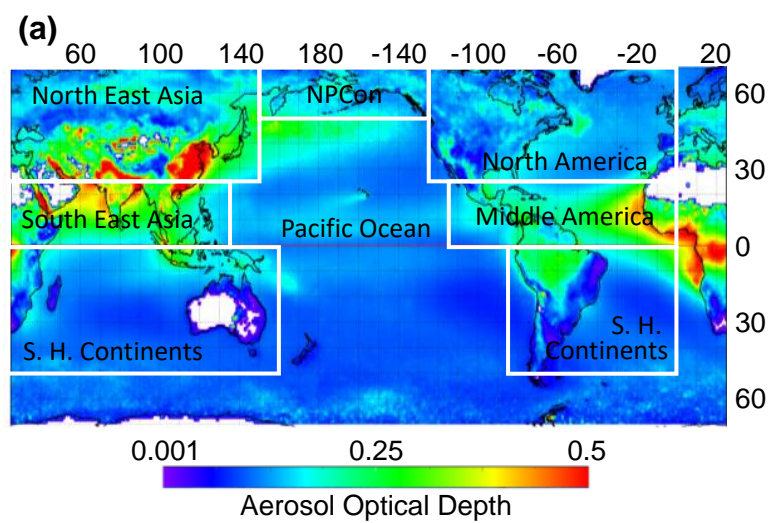

(b)

Aerosol Optical Depth

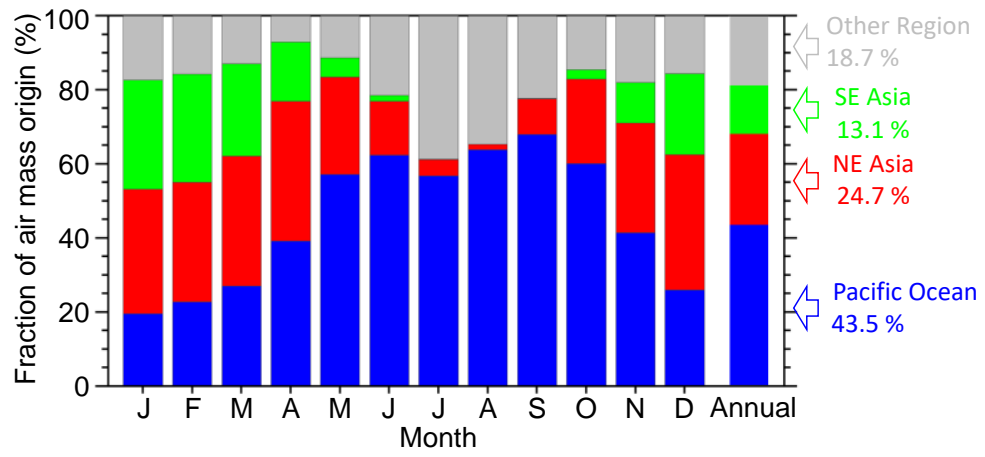

Fig. 2. (a) Source region designation for quantification of their contributions on the free troposphere (FT) $\sigma_{\mathrm{sp}}$ and $\sigma_{\mathrm{ap}}$ values measured at the MLO. The background color contour is a composite of monthly averaged Moderate Resolution Imaging Spectroradiometer (MODIS) Aqua dark target aerosol optical depth (AOD) from 2003 to 2015 (Level $3,1^{\circ} \times 1^{\circ}$ resolution). (b) Monthly variations of air mass source regions. Monthly frequencies of air masses from the Pacific Ocean (PO; blue), Northeast Asia (NE Asia; red), Southeast Asia (SE Asia; green), and other regions (OR; gray).

though the MLO is typically located above the trade wind inversion (TWI) layer. This is attributed to the weakened TWI due to the increased thermal instability together with an updraft induced from large-scale circulation (Hastenrath, 1991).

\section{Aerosol Optical Properties}

Monthly variations of $\sigma_{\mathrm{sp}}, \sigma_{\mathrm{ap}}, \mathrm{SAE}$, and SSA are shown in Fig. 3. The distinct springtime peaks of $\sigma_{\mathrm{sp}}$ and $\sigma_{\mathrm{ap}}$ are apparent in both the 24-h and LLI-h periods. Both the $\sigma_{\text {sp }}$ and $\sigma_{\text {ap }}$ values at $550 \mathrm{~nm}$ during the spring months (March-May) were $4.52 \pm 7.35 \mathrm{Mm}^{-1}$ and $0.49 \pm 0.59 \mathrm{Mm}^{-1}$, respectively. These were almost twice as large as the annual mean $\left(\sigma_{\mathrm{sp}}: 2.47\right.$ $\left.\pm 4.99 \mathrm{Mm}^{-1} ; \sigma_{\mathrm{ap}}: 0.28 \pm 0.45 \mathrm{Mm}^{-1}\right)$. Similarly, the values of $\sigma_{\mathrm{sp}}$ and $\sigma_{\mathrm{ap}}$ in FT conditions (i.e., during LLI hours) during the spring exhibited values approximately twice as large $\left(3.55 \pm 4.79 \mathrm{Mm}^{-1}\right.$ and $0.49 \pm 0.52 \mathrm{Mm}^{-1}$, respectively) as their annual mean values $\left(\sigma_{\mathrm{sp}}: 1.85 \pm 3.43 \mathrm{Mm}^{-1} ; \sigma_{\mathrm{ap}}: 0.29\right.$ $\pm 0.42 \mathrm{Mm}^{-1}$ ). Enhanced $\sigma_{\mathrm{sp}}$ and $\sigma_{\mathrm{ap}}$ values in FT conditions during the spring can be explained by the FT transport of aerosols, particularly from the Asian continent.

SÅE was relatively low in the spring compared with summer and autumn. This can be explained by the relatively coarse dust particles from NE Asia. Monthly mean SSA at $550 \mathrm{~nm}$ ranged between 0.83 and 0.88 from October to April, while it remained $>0.9$ during the summer. Observations of SSA smaller than 0.8 during the autumn can be attributed to preferential scavenging of light-scattering aerosols by clouds, fog and/or precipitation at low $-\sigma_{\mathrm{sp}}$ and $-\sigma_{\mathrm{ap}}$ conditions (Andrews et al., 2011). Frequent transport of light-absorbing aerosols from NE and SE Asia is responsible for low SSA values from January to April.

Figs. 4 and 5 show the monthly variations of $\sigma_{\mathrm{sp}}$ and $\sigma_{\mathrm{ap}}$ in FT conditions according to the airmass origin, and the contributions of each airmass source region on $\sigma_{\mathrm{sp}}$ and $\sigma_{\mathrm{ap}}$. We note that the contribution of the airmass origin $\left(C_{\sigma i, j}\right)$ to $\sigma_{\mathrm{sp}}\left(\sigma_{\mathrm{ap}}\right)$ was normalized for the $i^{\text {th }}$ source region and $j^{\text {th }}$ month:

$$
C_{\sigma_{i, j}}=\sigma_{s p(a p)_{i, j}}\left(\frac{N_{i, j}}{N_{j}}\right)
$$

where $N$ is the number of events. Elevated $\sigma_{\mathrm{sp}}$ and $\sigma_{\mathrm{ap}}$ values were apparent in the spring with prevailing airmass transportation from NE and SE Asia. It should be noted that monthly variations of $\sigma_{\mathrm{sp}}$ and $\sigma_{\mathrm{ap}}$ do not always coincide with the frequency of airmass source regions. Compared to the spring, more airmasses from NE and SE Asia reached the MLO in the winter. However, Asian airmasses contribute more to elevated $\sigma_{\mathrm{sp}}\left(\sigma_{\mathrm{ap}}\right)$ values in the spring. For example, the contributions of transported aerosols over long ranges from NE Asia (i.e., pollution and Asian dust particles) and from SE Asia (i.e., biomass burning aerosols which is listed 


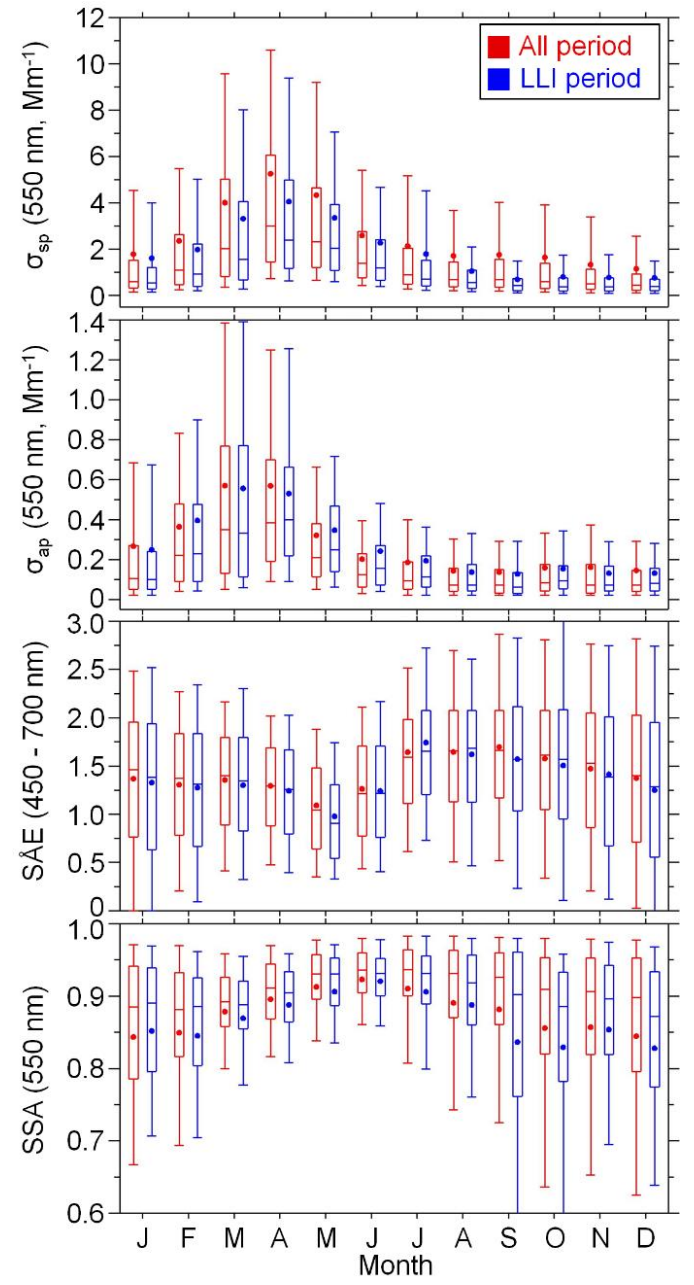

Fig. 3. Monthly variation of AOPs $\left(\sigma_{\mathrm{sp}}, \sigma_{\mathrm{ap}}, \mathrm{S} \AA \mathrm{E}\right.$ and SSA) observed at the MLO. The whiskers represent the $10^{\text {th }}$ and $90^{\text {th }}$ percentiles, and the horizontal lines in boxes represent the $25^{\text {th }}, 50^{\text {th }}$, and $75^{\text {th }}$ percentiles of monthly data. Monthly averages are denoted as dots. Percentiles of 24-h measurements are shown in red, while percentiles of LLI-h data are shown in blue.

in parenthesis) in March were estimated to be $45 \%$ (26\%) for $\sigma_{\mathrm{sp}}$ and $40 \%(25 \%)$ for $\sigma_{\mathrm{ap}}$. This temporal discrepancy between AOPs and the frequency of airmass impacting MLO is attributed to atmospheric conditions at the source regions as discussed below.

Although pollution emission is generally maximized during the winter in NE Asia, an increased atmospheric stability over NE Asia during the wintertime due to the development of the Siberian High inhibits the entrainment of aerosols from the boundary layer to FT (Cai et al., 2017). However, more favorable atmospheric conditions for the entrainment to FT occur in the spring, including the more frequent occurrence of frontal lifting (Bey et al., 2001). In SE Asia, large-scale biomass burning frequently occurs from January to April. These biomass burning aerosols can be entrained from a boundary layer to FT by atmospheric convection, and then further transported to downwind regions (Garreaud, 2001; Liu et al., 2003; Lee et al., 2017; Nam et al., 2018;
Park et al., 2019). Airmasses in the mid-troposphere tend to move westward from the late spring due to the influences from the Tibetan High (Liu et al., 2003), so the transport of aerosols from SE Asia to MLO is subsequently decreased. Interestingly, airmasses which travel only within the PO during the spring yield higher $\sigma_{\mathrm{sp}}$ and $\sigma_{\mathrm{ap}}$ values compared to other months (Fig. 4). This is because the Asian aerosols, which are extensively distributed over the Pacific, can also reach MLO. More investigations on aerosol loadings and associated aerosol optical and radiative properties over broad Pacific regions during the spring are thus needed (Brock et al., 2019; Katich et al., 2018).

\section{Systematic Relationships Among AOPs}

We investigated the relationships among AOPs for three major contributing source regions (PO, NE Asia, and SE Asia) to explore the aerosol characteristics, such as their types, sources, and processes (Andrews et al., 2011; Sherman et al., 2015; Schmeisser et al., 2017). Statistical comparisons of $\sigma_{\mathrm{sp}}$ and $\sigma_{\mathrm{ap}}$ for three source regions are listed in Table 3. The highest $\sigma_{\mathrm{sp}}$ and $\sigma_{\mathrm{ap}}$ values were apparent in the NE Asian airmass, whereas the PO airmass yielded the lowest values.

As $\sigma_{\mathrm{sp}}$ increases, $\sigma_{\mathrm{ap}}$ also increases in all three regions (Fig. 6(a)). The higher slope between $\sigma_{\mathrm{sp}}$ and $\sigma_{\mathrm{ap}}$ for the airmass from SE Asia suggests that the aerosols from SE Asia have a lower SSA than others, as shown in Fig. 6(b). Similarly, SSA also gradually increases as $\sigma_{\mathrm{sp}}$ increases. Selective scavenging of larger scattering aerosols is possible given that the removal of larger particles generally result in low aerosol concentration with higher absorption parts over the total extinction (Sellegri et al., 2003; Andrews et al., 2011). Contrary to the PO and SE Asia, SÅE gradually decreases with increasing $\sigma_{\mathrm{sp}}$ for the airmass from NE Asia (Fig. 6(c)). This relationship can be explained by the transport of coarse dust particles from arid and desert areas in NE Asia (Lee et al., 2012). An increasing SÅE with increasing $\sigma_{\mathrm{sp}}$ values for SE Asian airmasses is likely attributed to the fine-mode biomass burning aerosols (Toledano et al., 2007; Andrews et al., 2011; Schmeisser et al., 2017). SÅE and A A E between NE and SE Asia are similar, but slightly higher $\mathrm{SA} E$ and lower A $A \mathrm{E}$ were observed in PO airmass (not shown).

\section{Inter-annual Trend of Aerosol Scattering and Absorption Coefficients}

The trends of $\sigma_{\mathrm{sp}}$ and $\sigma_{\mathrm{ap}}$ in FT conditions were calculated for three major source regions (NE Asia, SE Asia, and PO). Fig. 7(a) shows the time series of the annual mean $\sigma_{\text {sp }}$ and $\sigma_{a p}$ values over the study period. A linear trend and its significance calculated with the Theil-Sen and Mann-Kendall methods is presented in Fig. 7(b). The value of $\sigma_{\mathrm{sp}}$ increased by approximately $+1.89 \%$ per year during the period of 1974-2015. The highest increasing trend of $\sigma_{\mathrm{sp}}$ since 1974 appeared in the PO air mass $\left(+2.18 \%\right.$ year $\left.^{-1}\right)$, followed by NE Asia $\left(+2.09 \%\right.$ year $\left.^{-1}\right)$ and SE Asia $\left(+1.22 \%\right.$ year $\left.^{-1}\right)$. However, the magnitude of the increasing trend adhered to the order of a) NE Asia $\left(+0.51 \mathrm{Mm}^{-1}\right.$ decade $\left.^{-1}\right)$, b) PO $\left(+0.32 \mathrm{Mm}^{-1}\right.$ decade $\left.^{-1}\right)$, and c) SE Asia $\left(+0.27 \mathrm{Mm}^{-1} \mathrm{decade}^{-1}\right)$. 


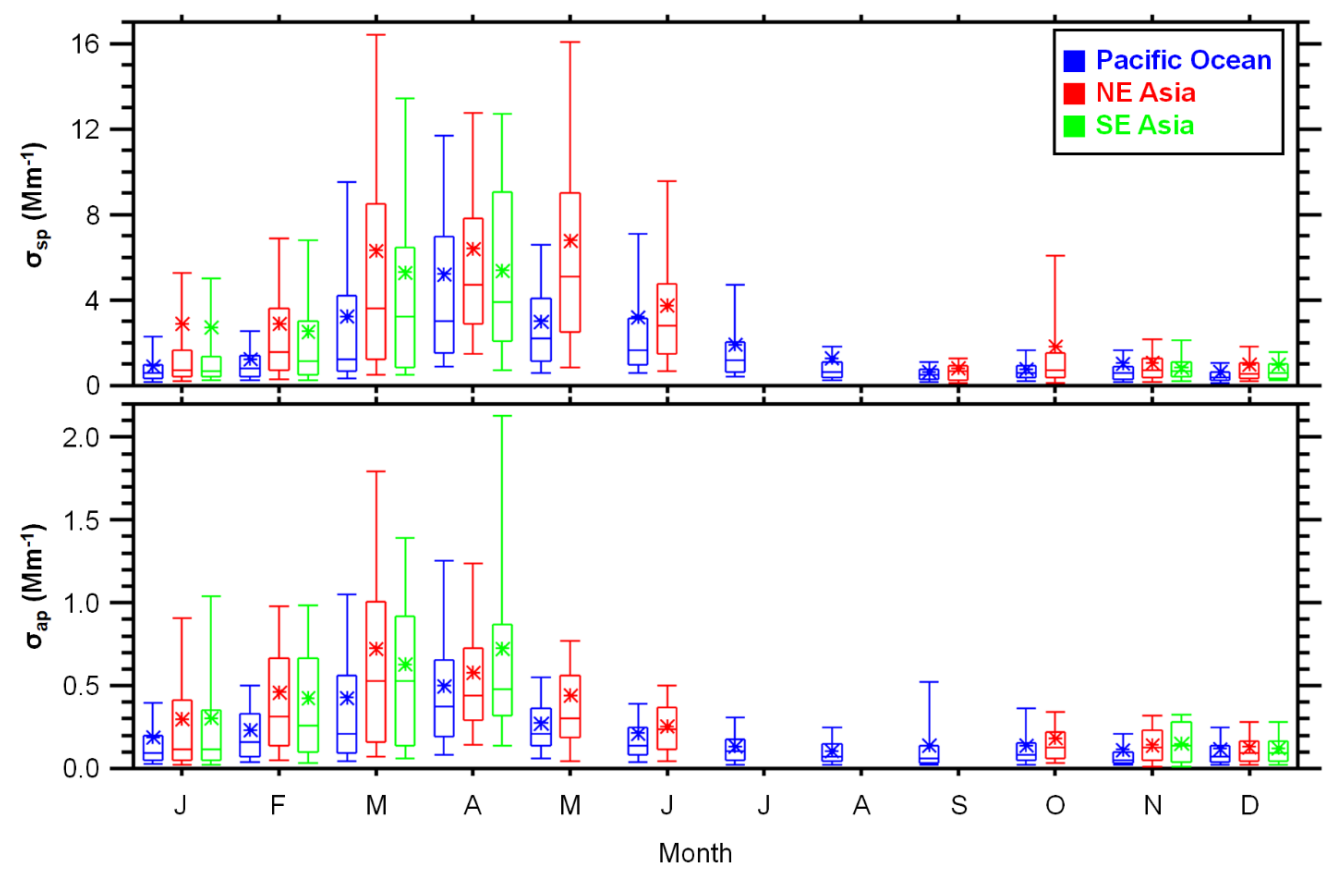

Fig. 4. Monthly variations of $\sigma_{\mathrm{sp}}$ and $\sigma_{\mathrm{ap}}$ for the air masses from the PO, NE Asia, and SE Asia regions. Cross lines in boxes represent the $25^{\text {th }}, 50^{\text {th }}$, and $75^{\text {th }}$ percentiles, and whiskers represent the $10^{\text {th }}$ and $90^{\text {th }}$ percentiles. Mean values of each month are denoted by asterisks. Data for $\sigma_{\text {sp }}$ and $\sigma_{\text {ap }}$ from the period of 2000-2015 are utilized.

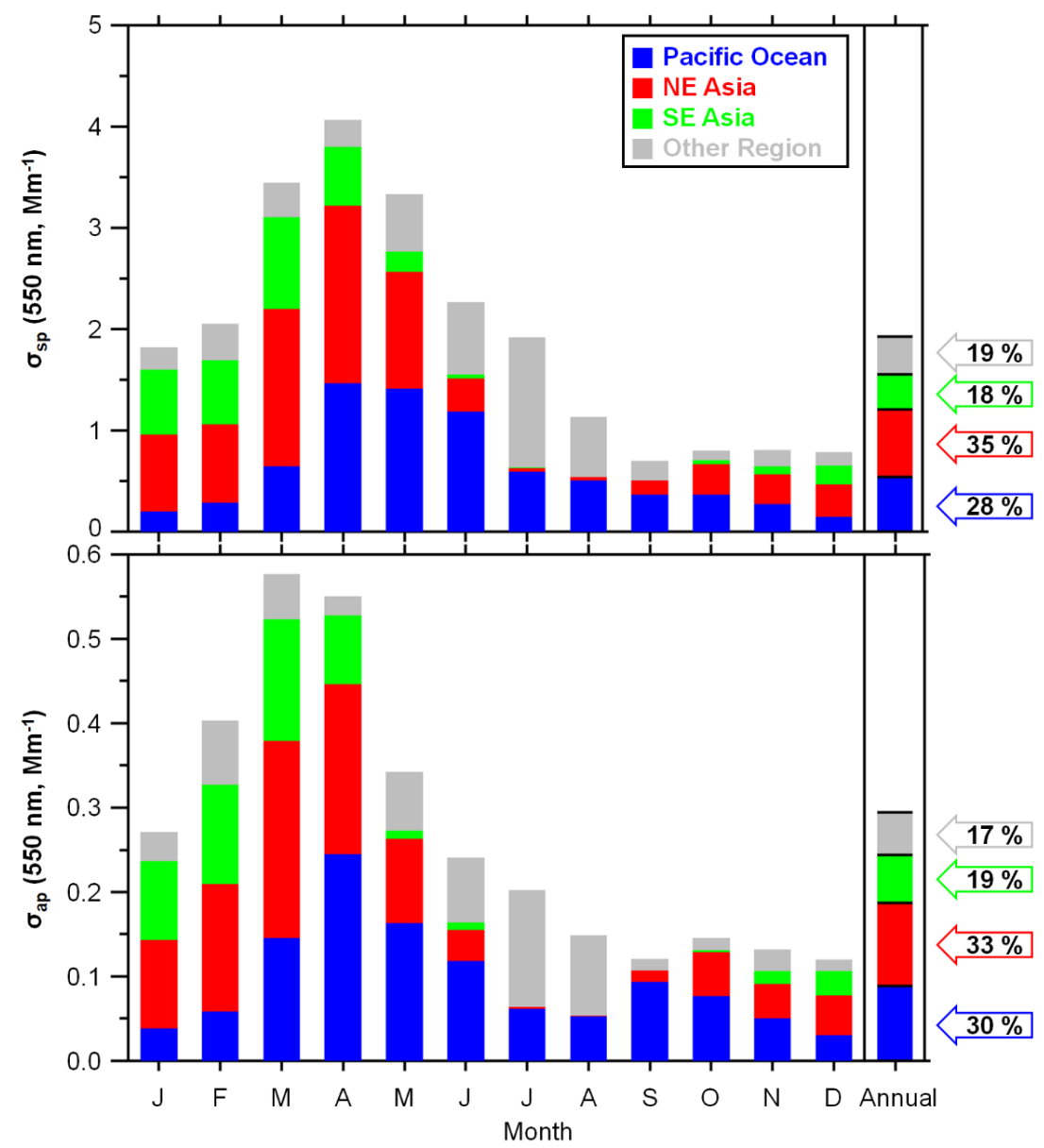

Fig. 5. Monthly variation of source region contributions on $\sigma_{\mathrm{sp}}$ and $\sigma_{\mathrm{ap}}$ at the MLO. PO, NE Asia, SE Asia, and other regions (OR) are denoted with blue, red, green, and gray colors, respectively. 
Table 3. Comparison of aerosol scattering and absorption coefficients $(550 \mathrm{~nm})$ among different source regions.

\begin{tabular}{llllll}
\hline Properties & & Pacific Ocean & Northeast Asia & Southeast Asia & Other regions $^{a}$ \\
\hline Aerosol scattering & Mean & 1.457 & 2.456 & 2.243 & 1.828 \\
coefficient & Median & 0.64 & 0.93 & 0.83 & 0.68 \\
$\left(550 \mathrm{~nm}, \mathrm{Mm}^{-1}\right)$ & Standard error & 0.034 & 0.064 & 0.082 & 0.060 \\
Aerosol absorption & Mean & 0.229 & 0.358 & 0.352 & 0.273 \\
coefficient & Median & 0.126 & 0.187 & 0.161 & 0.012 \\
$\left(550 \mathrm{~nm}, \mathrm{Mm}^{-1}\right)$ & Standard error & 0.0078 & 0.0133 & 0.0171 & 0.015 \\
\hline
\end{tabular}

${ }^{a}$ Includes North America, Central America, Southern Hemispheric continents and North Pacific Continents.

(a)

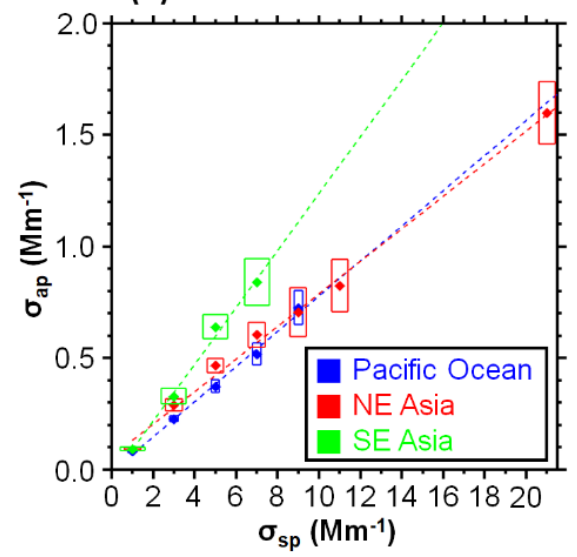

(b)

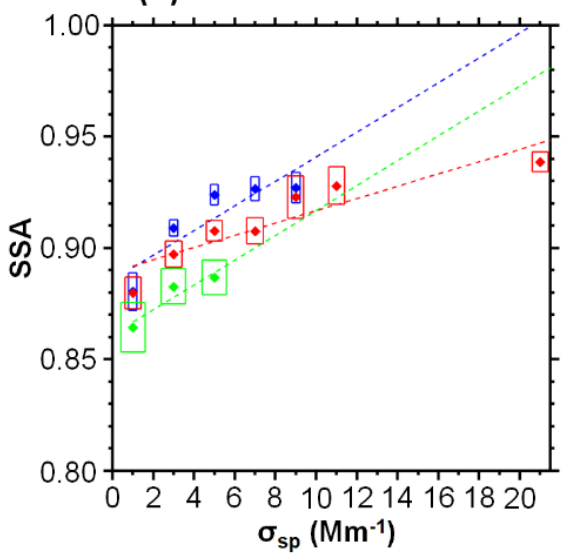

(c)

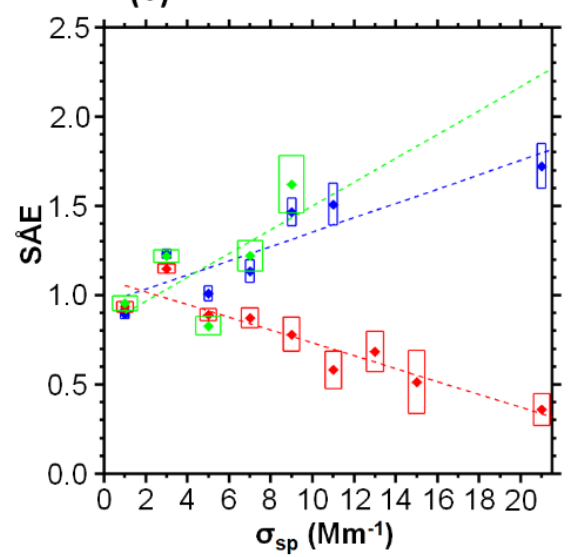

Fig. 6. Systematic relationship between the FT AOPs at the MLO analyzed according to the source region. Red, green, and blue colors respectively indicate the NE Asia, SE Asia, and PO regions. (a-c) Systematic relations among $\sigma_{\mathrm{sp}}$ and other AOPs, such as $\sigma_{\text {ap }}$, single-scattering albedo (SSA), and scattering Ångström exponent (SÅE). The average values of variables correspond to each $\sigma_{\mathrm{sp}}$ bin, which is divided in $2 \mathrm{Mm}^{-1}$ intervals, are denoted by filled diamonds with the respective colors used for each source region. Horizontal lines in boxes represent standard errors. Bins with more than 20 valid measurements are analyzed. Linear regression lines over each source region are denoted with dotted lines using the respective colors for the studied regions.

(a)
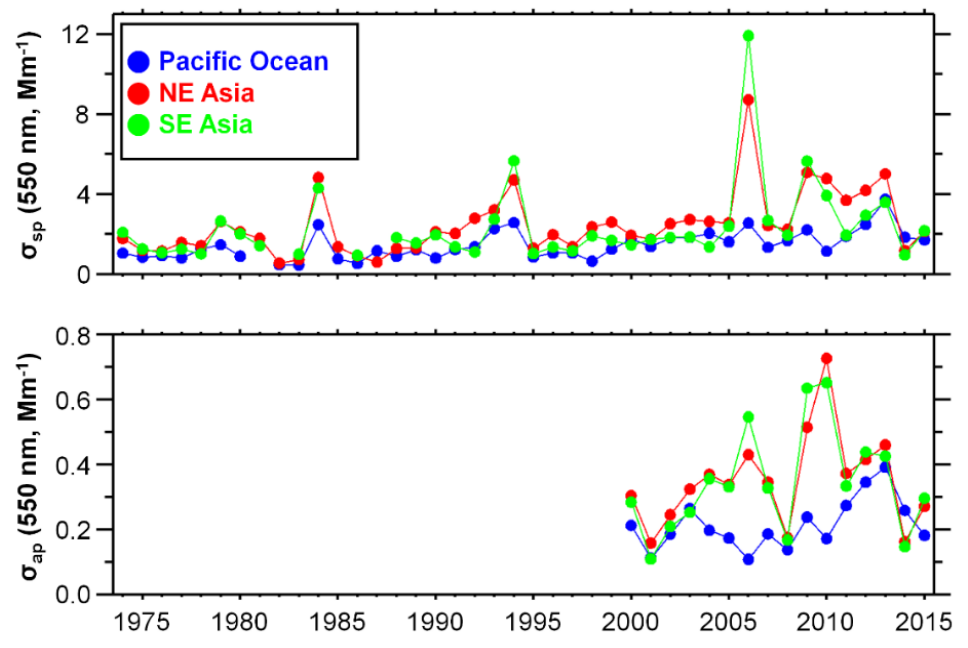

(b)

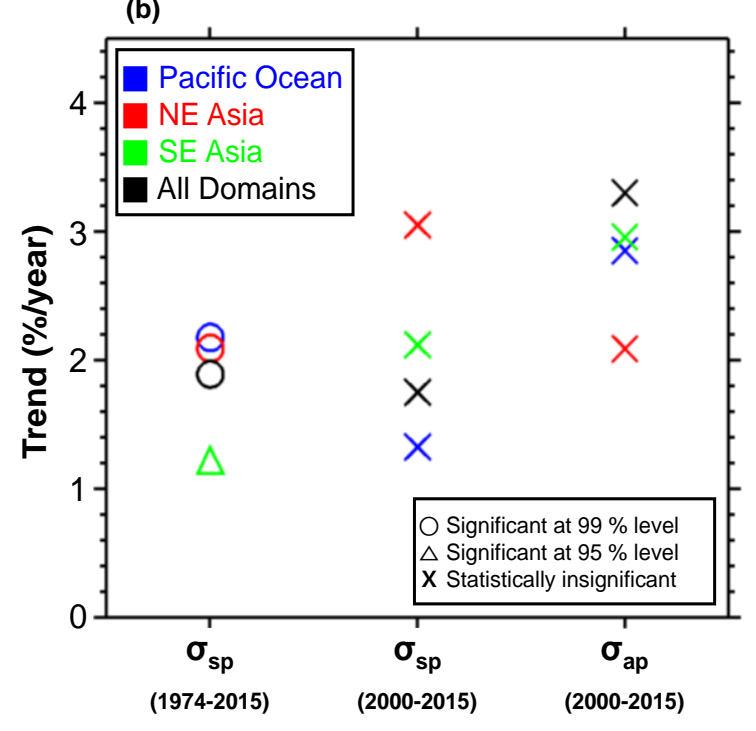

Fig. 7. (a) Time series of annual average $\sigma_{\mathrm{sp}}$ and $\sigma_{\mathrm{ap}}$ values according to the source region. Each source region is depicted in blue (PO), red (NE Asia), and green (SE Asia) colors. (b) Trends of $\sigma_{\mathrm{sp}}$ and $\sigma_{\mathrm{ap}}$ values according to the air mass origins. Trends and their statistical significances are calculated with the Theil-Sen slope method and the Mann-Kendall test, respectively. Significant trends at 99\% (95\%) confidence levels are denoted as circles (triangles), while crosses denote insignificant trends at a $95 \%$ confidence level. 
These first two trends (a, b) are significant at a $99 \%$ confidence level, and the last trend (c) at a 95\% confidence. Both the $\sigma_{\mathrm{sp}}$ and $\sigma_{\mathrm{ap}}$ values yield positive trends in all three regions during the period of 2000-2015, but both are insignificant at a $95 \%$ confidence level.

Overall, $\sigma_{\mathrm{sp}}$ and $\sigma_{\mathrm{ap}}$ at MLO is experiencing greater influence from LRT aerosol plumes. Especially, aerosol transport from NE Asia, associated with increasing anthropogenic emission due to the economic growth (and with some natural variation) was the most prominent contributing source for the increasing trend of the extensive AOPs (Liu et al., 2003; Guo et al., 2011; Kim et al., 2011; Chen and Wang, 2015). The positive trend in PO airmass is attributable to enhanced outflow of pollution aerosols from NE Asia, which finally reaches MLO. This is supported by the concurrent peak of $\sigma_{\mathrm{sp}}$ and $\sigma_{\mathrm{ap}}$ found during boreal spring when the source of air mass is PO, while the only possible FT source of aerosols are FT transport originating from NE and SE Asia.

\section{CONCLUSIONS}

We investigated diurnal, monthly, and inter-annual variations in the aerosol scattering coefficient $\left(\sigma_{\mathrm{sp}} ; 1974\right.$ $2015)$ and the absorption coefficient $\left(\sigma_{\mathrm{ap}} ; 2000-2015\right)$ at the MLO using surface in situ measurements. The major findings of this study are summarized below:

- The value of $\sigma_{\mathrm{sp}}$ decreased during the hours of 8-11 LST $\left(1.85 \pm 3.43 \mathrm{Mm}^{-1}\right.$ at $\left.550 \mathrm{~nm}\right)$ but increased during the afternoon $\left(3.72 \pm 7.63 \mathrm{Mm}^{-1}\right.$ at $\left.550 \mathrm{~nm} ; 14-17 \mathrm{LST}\right)$ due to the development of upslope boundary layer winds. No distinct diurnal variation was observed in $\sigma_{\mathrm{ap}}$.

- The highest $\sigma_{\mathrm{sp}}$ and $\sigma_{\mathrm{ap}}$ values appeared when the air masses originated in NE Asia $\left(\sigma_{\mathrm{sp}}: 2.46 \mathrm{Mm}^{-1} ; \sigma_{\mathrm{ap}}\right.$ : $\left.0.36 \mathrm{Mm}^{-1}\right)$, followed by SE Asia $\left(\sigma_{\mathrm{sp}}: 2.24 \mathrm{Mm}^{-1} ; \sigma_{\mathrm{ap}}\right.$ : $\left.0.35 \mathrm{Mm}^{-1}\right)$ and the PO ( $\left.\sigma_{\mathrm{sp}}: 1.46 \mathrm{Mm}^{-1} ; \sigma_{\mathrm{ap}}: 0.23 \mathrm{Mm}^{-1}\right)$.

- NE Asia and SE Asia were the most prominent sources of air masses during the winter, but their contributions to $\sigma_{\mathrm{sp}}$ and $\sigma_{\mathrm{ap}}$ values peaked during the spring.

- A distinct increase in the values of $\sigma_{\mathrm{sp}}$ and $\sigma_{\mathrm{ap}}$ during the spring under FT conditions (8-11 LST) was attributed to long-range-transported dust and pollution aerosols from NE Asia and biomass burning aerosols from SE Asia.

- The largest increasing trend for $\sigma_{\mathrm{sp}}$ after 1974 was attributed to air masses from the PO $\left(+2.18 \%\right.$ year $\left.^{-1}\right)$, followed by NE Asia $\left(+2.09 \%\right.$ year $\left.^{-1}\right)$ and SE Asia $\left(+1.22 \%\right.$ year $\left.^{-1}\right)$. However, the increasing trend's magnitude adhered to the order of a) NE Asia $(+0.51$ $\mathrm{Mm}^{-1}$ decade $\left.^{-1}\right)$, b) the PO $\left(+0.32 \mathrm{Mm}^{-1}\right.$ decade $\left.^{-1}\right)$, and c) SE Asia $\left(+0.27 \mathrm{Mm}^{-1}\right.$ decade $\left.^{-1}\right)$. Both the $\sigma_{\mathrm{sp}}$ and $\sigma_{\mathrm{ap}}$ values showed positive trends for all three regions over the period of 2000-2015, but these values were insignificant at a $95 \%$ confidence level.

Long-term, continuous climate-relevant aerosol measurements at the MLO are needed in the future to better estimate the direct aerosol radiative effects related to emissions from Asia. In particular, simultaneous measurements of aerosol chemical components will be very helpful in identifying the aerosol sources.

\section{ACKNOWLEDGEMENTS}

This study was supported by the Basic Science Research Program through the National Research Foundation of Korea (NRF) funded by the Ministry of Education (2017R1D1A1B06032548) and the Korea Meteorological Administration Research and Development Program under Grant KMI2018-01111. Authors are also thankful to operators and technicians at Mauna Loa Observatory for supporting the measurements by conducting maintenance and calibrations of instruments.

\section{SUPPLEMENTARY MATERIAL}

Supplementary data associated with this article can be found in the online version at http://www.aaqr.org.

\section{REFERENCES}

Anderson, T.L. and Ogren, J.A. (1998). Determining aerosol radiative properties using the TSI 3563 integrating nephelometer. Aerosol Sci. Technol. 29: 57-69. https://doi.org/10.1080/02786829808965551

Andrews, E., Ogren, J.A., Bonasoni, P., Marinoni, A., Cuevas, E., Rodríguez, S., Sun, J.Y., Jaffe, D.A., Fischer, E.V., Baltensperger, U., Weingartner, E., Coen, M.C., Sharma, S., Macdonald, A.M., Leaitch, W.R., Lin, N.H., Laj, P., Arsov, T., Kalapov, I., Jefferson, A. and Sheridan, P. (2011). Climatology of aerosol radiative properties in the free troposphere. Atmos. Res. 102: 365-393. https://doi.org/10.1016/j.atmosres.2011.08.017

Andrews, E., Sheridan, P.J., Ogren, J.A., Hageman, D., Jefferson, A., Wendell, J., Alástuey, A., Alados-Arboledas, L., Bergin, M., Ealo, M., Gannet Hallar, A., Hoffer, A., Kalapov, I., Keywood, M., Kim, J., Kim, S.W., Kolonjari, F., Labuschagne, C., Lin, N.H., Macdonald, A., MayolBracero, O.L., McCubbin, I.B., Pandolfi, M., Reisen, F., Sharma, S., Sherman, J.P., Sorribas, M. and Sun, J. (2019). Overview of the NOAA/ESRL federated aerosol network. Bull. Am. Meteorol. Soc. 100: 123-135. https://doi.org/ 10.1175/BAMS-D-17-0175.1

Bergstrom, R.W., Russell, P.B. and Hignett, P. (2002). Wavelength dependence of the absorption of black carbon particles: Predictions and results from the TARFOX experiment and implications for the aerosol single scattering albedo. J. Atmos. Sci. 59: 567-577. https://doi.org/10.1175/1520-0469(2002)059<0567:WD OTAO $>2.0 . \mathrm{CO} ; 2$

Bey, I., Jacob, D.J., Logan, J.A. and Yantosca, R.M. (2001). Asian chemical outflow to the Pacific in spring: Origins, pathways, and budgets. J. Geophys. Res. 106: 2309723113. https://doi.org/10.1029/2001JD000806

Bodhaine, B.A., Mendonca, B.G., Harris, J.M. and Miller, M. (1981). Seasonal variations in aerosols and atmospheric transmission at Mauna Loa Observatory. J. Geophys. Res. 86: 7395-7398. https://doi.org/10.1029/JC086iC08p07395

Bodhaine, B.A. (1995). Aerosol absorption measurements at Barrow, Mauna Loa and aerosol have also been measured continuously for many years is consistent with 
specific absorption of $\mathrm{BC}$ on the aethalometer specific absorption atmosphere measurements of the wavelength dependence. J. Geophys. Res. 100: 8967-8975. https://doi.org/10.1029/95JD00513

Bodhaine, B.A. (1996). Aerosol measurements during the Mauna Loa Photochemistry Experiment 2. J. Geophys. Res. 101: 14757-14765. https://doi.org/10.1029/95JD02045

Bond, T.C., Anderson, T.L. and Campbell, D. (1999). Calibration and intercomparison of filter-based measurements of visible light absorption by aerosols. Aerosol Sci. Technol. 30: 582-600. https://doi.org/10.10 80/027868299304435

Boucher, O., Randall, D., Artaxo, P., Bretherton, C., Feingold, G., Forster, P., Kerminen, V.M., Kondo, Y., Liao, H., Lohmann, U., Rasch, P., Satheesh, S.K., Sherwood, S., Stevens, B. and Zhang, X.Y. (2013). Clouds and Aerosols. In Climate Change 2013: The Physical Science Basis. Contribution of Working Group I to the Fifth Assessment Report of the Intergovernmental Panel on Climate Change, Stocker, T.F., Qin, D., Plattner, G.K., Tignor, M., Allen, S.K., Boschung, J., Nauels, A., Xia, Y., Bex, V. and Midgley, P.M. (Eds.), Cambridge University Press.

Brock, C.A., Williamson, C., Kupc, A., Froyd, K.D., Erdesz, F., Wagner, N., Richardson, M., Schwarz, J.P., Gao, R.S., Katich, J.M., Campuzano-Jost, P., Nault, B.A., Schroder, J.C., Jimenez, J.L., Weinzierl, B., Dollner, M., Bui, T. and Murphy, D.M. (2019). Aerosol size distributions during the Atmospheric Tomography Mission (ATom): Methods, uncertainties, and data products. Atmos. Meas. Tech. 12: 3081-3099. https://doi.org/10.5194/amt-12-3081-2019

Cai, W., Li, K., Liao, H., Wang, H. and Wu, L. (2017). Weather conditions conducive to Beijing severe haze more frequent under climate change. Nat. Clim. Change 7: 257-262. https://doi.org/10.1038/nclimate3249

Chambers, S., Williams, A.G., Zahorowski, W., Griffiths, A. and Crawford, J. (2011). Separating remote fetch and local mixing influences on vertical radon measurements in the lower atmosphere. Tellus $B$ 63: 843-859. https://doi.org/10.1111/j.1600-0889.2011.00565.x

Chambers, S.D., Zahorowski, W., Williams, A.G., Crawford, J. and Griffiths, A.D. (2013). Identifying tropospheric baseline air masses at mauna loa observatory between 2004 and 2010 using radon-222 and back trajectories. $J$. Geophys. Res. 118: 992-1004. https://doi.org/10.1029/20 12JD018212

Chambers, S.D., Williams, A.G., Conen, F., Griffiths, A.D., Reimann, S., Steinbacher, M., Krummel, P.B., Steele, L.P., van der Schoot, M.V., Galbally, I.E., Molloy, S.B. and Barnes, J.E. (2016). Towards a universal "Baseline" characterisation of air masses for high- and low-altitude observing stations using radon-222. Aerosol Air Qual. Res. 16: 885-899. https://doi.org/10.4209/aaqr.2015.06.0 391

Chen, H. and Wang, H. (2015). Haze Days in North China and the associated atmospheric circulations based on daily visibility data from 1960 to 2012. J. Geophys. Res. 120: 5895-5909. https://doi.org/10.1002/2015JD023225

Collaud Coen, M., Andrews, E., Asmi, A., Baltensperger, U., Bukowiecki, N., Day, D., Fiebig, M., Fjaeraa, A.M.,
Flentje, H., Hyvärinen, A., Jefferson, A., Jennings, S.G., Kouvarakis, G., Lihavainen, H., Lund Myhre, C., Malm, W.C., Mihapopoulos, N., Molenar, J.V., O’Dowd, C., Ogren, J.A., Schichtel, B.A., Sheridan, P., Virkkula, A., Weingartner, E., Weller, R. and Laj, P. (2013). Aerosol decadal trends-Part 1: In-situ optical measurements at GAW and IMPROVE stations. Atmos. Chem. Phys. 13: 869-894. https://doi.org/10.5194/acp-13-869-2013

Darzi, M. and Winchester, W. (1982). Aerosol characteristics at Mauna Loa Observatory, Hawaii, after east Asian dust storm episodes. J. Geophys. Res. 87: 1251-1258. https://doi.org/10.1029/JC087iC02p01251

Delene, D.J. and Ogren, J.A. (2002). Variability of aerosol optical properties at four North American surface monitoring sites. J. Atmos. Sci. 59: 1135-1150. https://doi.org/10.1175/1520-0469(2002)059<1135:VO AOPA $>2.0 . \mathrm{CO} ; 2$

Draxler, R.R. and Hess, G.D. (1998). An overview of the HYSPLIT_4 modelling system for trajectories, dispersion, and deposition. Aust. Meteorol. Mag. 47: 295-308.

Eck, T.F., Holben, B.N., Dubovik, O., Smirnov, A., Goloub, P., Chen, H.B., Chatenet, B., Gomes, L., Zhang, X.Y., Tsay, S.C., Ji, Q., Giles, D. and Slutsker, I. (2005). Columnar aerosol optical properties at AERONET sites in central eastern Asia and aerosol transport to the tropical mid-Pacific. J. Geophys. Res. 110: 1-18. https://doi.org/10.1029/2004JD005274

Garreaud, R.D. (2001). Subtropical cold surges: Regional aspects and global distribution. Int. J. Climatol. 21: 1181-1197. https://doi.org/10.1002/joc.687

Gilbert, R.O. (1987). Statistical Methods for Environmental Pollution Monitoring. Van Nostrand Reinhold Company Inc., New York.

Guo, J.P., Zhang, X.Y., Wu, Y.R., Zhaxi, Y., Che, H.Z., La, B., Wang, W. and Li, X.W. (2011). Spatio-temporal variation trends of satellite-based aerosol optical depth in China during 1980-2008. Atmos. Environ. 45: 68026811. https://doi.org/10.1016/j.atmosenv.2011.03.068

Hansen, J., Rossow, W., Carlson, B., Lacis, A., Travis, L., Del Genio, A., Fung, I., Cairns, B., Mishchenko, M. and Sato, M. (1995). Forcings and Feedbacks. Clim. Change. 31: 247-271.

Harris, J.M. and Kahl, J.D. (1990). A descriptive atmospheric transport climatology for the Mauna Loa Observatory, using clustered trajectories. J. Geophys. Res. 95: 13651-13667. https://doi.org/10.1029/JD095iD 09p13651

Hastenrath, S. (1991). Climate Dynamics of the Tropics. Springer. Netherlands. https://doi.org/10.1007/978-94011-3156-8

Haywood, J.M. and Ramaswamy, V. (1998). Global sensitivity studies of the direct radiative forcing due to anthropogenic sulfate and black carbon aerosols. $J$. Geophys. Res. 103: 6043-6058. https://doi.org/10.1029/ 97JD03426

Henderson-Sellers, A. and Robinson, P.J. (1991). Contemporary climatology. John Wiley. New York.

Jacobson, M.Z. (2002). Control of fossil-fuel particulate black carbon and organic matter, possibly the most 
effective method of slowing global warming. J. Geophys. Res. 107: ACH 16-1-ACH 16-22. https://doi.org/10.1029 /2001JD001376

Kalnay, E., Kanamitsu, M., Kistler, R., Collins, W., Deaven, D., Gandin, L., Iredell, M., Saha, S., White, G., Woollen, J., Zhu, Y., Chelliah, M., Ebisuzaki, W., Higgins, W., Janowiak, J., Mo, K.C., Ropelewski, C., Wang, J., Leetmaa, A., Reynolds, R., Jenne, R. and Joseph, D. (1996). The NCEP NCAR 40-Year Reanalysis Project. Bull. Am. Meteorol. Soc. 77: 437-472. https://doi.org/10.1175/152 0-0477(1996)077<0437:TNYRP>2.0.CO;2

Katich, J.M., Samset, B.H., Paul Bui, T., Dollner, M., Froyd, K.D., Campuzano-Jost, P., Nault, B.A., Schroder, J.C., Weinzierl, B. and Schwarz, J.P. (2018). Strong contrast in remote black carbon aerosol loadings between the Atlantic and Pacific basins. J. Geophys. Res. 123: 13386-13395. https://doi.org/10.1029/2018JD029206

Kendall, M.G. (1975). Rank correlation methods. 4th ed. Charles Griffin. London.

Kent, G.S., Trepte, C.R. and Lucker, P.L. (1998). Longterm stratospheric aerosol and gas experiment I and II measurements of upper tropospheric aerosol extinction. J. Geophys. Res. 103: 28863-28874. https://doi.org/10.1 029/98JD02583

Kim, N.K., Kim, Y.P. and Kang, C.H. (2011). Long-term trend of aerosol composition and direct radiative forcing due to aerosols over Gosan: TSP, $\mathrm{PM}_{10}$, and $\mathrm{PM}_{2.5}$ data between 1992 and 2008. Atmos. Environ. 45: 6107-6115. https://doi.org/10.1016/j.atmosenv.2011.08.051

Laj, P., Klausen, J., Bilde, M., Plaß-Duelmer, C., Pappalardo, G., Clerbaux, C., Baltensperger, U., Hjorth, J., Simpson, D., Reimann, S., Coheur, P.F., Richter, A., De Mazière, M., Rudich, Y., McFiggans, G., Torseth, K., Wiedensohler, A., Morin, S., Schulz, M., ... Zardini, A.A. (2009). Measuring atmospheric composition change. Atmos. Environ. 43: 5351-5414. https://doi.org/10.1016/j.atmose nv.2009.08.020

Lee, G., Merrill, J.T. and Huebert, J. (1994). Variation of free tropospheric total nitrate at Mauna Loa Observatory, Hawaii. J. Geophys. Res. 99: 12821-12831. https://doi.org /10.1029/94JD00146

Lee, H.H., Bar-Or, R.Z. and Wang, C. (2017). Biomass burning aerosols and the low-visibility events in Southeast Asia. Atmos. Chem. Phys. 17: 965-980. https://doi.org/10. 5194/acp-17-965-2017

Lee, S., Yoon, S.C., Kim, S.W., Kim, Y.P., Ghim, Y.S., Kim, J.H., Kang, C.H., Kim, Y.J., Chang, L.S. and Lee, S.J. (2012). Spectral dependency of light scattering/absorption and hygroscopicity of pollution and dust aerosols in Northeast Asia. Atmos. Environ. 50: 246-254. https://doi.org/10.1016/j.atmosenv.2011.12.026

Liu, H., Jacob, D.J., Bey, I., Yantosca, R.M., Duncan, B.N. and Sachse, G.W. (2003). Transport pathways for Asian pollution outflow over the Pacific: Interannual and seasonal variations. J. Geophys. Res. 108: GTE 7-1-GTE 7-15. https://doi.org/10.1029/2002JD003102

Mann, H.B. (1945). Nonparametric tests against trend. Econometrica 13: 245-259.

Mattis, I., Müller, D., Ansmann, A., Wandinger, U.,
Preißler, J., Seifert, P. and Tesche, M. (2008). Ten years of multiwavelength Raman lidar observations of freetropospheric aerosol layers over central Europe: Geometrical properties and annual cycle. J. Geophys. Res. 113: D20202. https://doi.org/10.1029/2007JD009636

McKendry, I.G., Hacker, J.P., Stull, R., Sakiyama, S., Mignacca, D. and Reid, K. (2001). Long-range transport of Asian dust to the Lower Fraser Valley, British Columbia, Canada. J. Geophys. Res. 106: 18361-18370. https://doi.org/10.1029/2000JD900359

Mendoca, B.G. (1969). Local wind circulation on the slope of Mauna Loa. J. Appl. Meteorol. 8: 533-541. https://doi.org/10.1175/1520-0450(1969)008<0533:LW COTS $>2.0 . \mathrm{CO} ; 2$

Merrill, J.T., Uematsu, M. and Bleck, R. (1989). Meteorological analysis of long range transport of mineral aerosols over the North Pacific. J. Geophys. Res. 94: 8584-8598. https://doi.org/10.1029/JD094iD06p08584

Miller, J.M. (1981). A five-year climatology of back trajectories from the Mauna Loa Observatory, Hawaii. Atmos. Environ. 15: 1553-1558. https://doi.org/10.1016/ 0004-6981(81)90138-4

Nam, J., Kim, S.W., Park, R.J., Park, J.S. and Park, S.S. (2018). Changes in column aerosol optical depth and ground-level particulate matter concentration over East Asia. Air Qual. Atmos. Health 11: 49-60. https://doi.org/ 10.1007/s11869-017-0517-5

Ogren, J.A. (2010). Comment on "Calibration and intercomparison of filter-based measurements of visible light absorption by aerosols". Aerosol Sci. Technol. 44: 589-591. https://doi.org/10.1080/02786826.2010.482111

Ogren, J.A., Wendell, J., Andrews, E. and Sheridan, P.J. (2017). Continuous light absorption photometer for longTerm studies. Atmos. Meas. Tech. 10: 4805-4818. https://doi.org/10.5194/amt-10-4805-2017

Park, S., Kim, S.W., Lin, N.H., Pani, S.K., Sheridan, P.J. and Andrews, E. (2019). Variability of aerosol optical properties observed at a polluted marine (Gosan, Korea) and a high-altitude mountain (Lulin, Taiwan) site in the Asian continental outflow. Aerosol Air Qual. Res. 19: 1272-1283. https://doi.org/10.4209/aaqr.2018.11.0416

Perry, K.D., Cahill, T.A., Schnell, R.C. and Harris, J.M. (1999). Long-range transport of anthropogenic aerosols to the National Oceanic and Atmospheric Administration baseline station at Mauna Loa Observatory, Hawaii. $J$. Geophys. Res. 104: 18521-18533. https://doi.org/10.102 9/1998JD100083

Research and Economic Analysis Division of the State Department of Business, Economic Development \& Tourism (DBEDT) (2019). Quarterly statistical and economic report-State of Hawaii. $3^{\text {rd }}$ Quarter 2019. Honolulu.

Ryan, S. (1997). The wind field around Mauna Loa derived from surface and balloon observations. J. Geophys. Res. 102: 10711-10725. https://doi.org/10.1029/97JD00646

Schery, S.D. and Huang, S. (2004). An estimate of the global distribution of radon emissions from the ocean. Geophys. Res. Lett. 31: L19104. https://doi.org/10.1029/ 2004GL021051 
Schmeisser, L., Andrews, E., Ogren, J.A., Sheridan, P., Jefferson, A., Sharma, S., Kim, J.E., Sherman, J.P., Sorribas, M., Kalapov, I., Arsov, T., Angelov, C., MayolBracero, O.L., Labuschagne, C., Kim, S.W., Hoffer, A., Lin, N.H., Chia, H.P., Bergin, M., Sun, J., Liu, P. and Wu, H. (2017). Classifying aerosol type using in-situ surface spectral aerosol optical properties. Atmos. Chem. Phys. 17: 12097-12120. https://doi.org/10.5194/acp-17-120972017

Schneider, T., Bischoff, T. and Haug, G.H. (2014). Migrations and dynamics of the intertropical convergence zone. Nature 513: 45-53. https://doi.org/10.1038/nature1 3636

Sellegri, K., Laj, P., Dupuy, R., Legrand, M., Preunkert, S. and Putaud, J.P. (2003). Size-dependent scavenging efficiencies of multicomponent atmospheric aerosols in clouds. J. Geophys. Res. 108: AAC 3-1-AAC 3-15. https://doi.org/10.1029/2002JD002749

Sharma, N.C.P. and Barnes, J.E. (2016). Boundary Layer Characteristics over a High Altitude Station, Mauna Loa Observatory. Aerosol Air Qual. Res. 16: 729-737. https://doi.org/10.4209/aaqr.2015.05.0347

Shaw, G.E. (1980). Transport of Asian Desert Aerosol to the Hawaiian Islands. J. Appl. Meteorol. 19: 1254-1259. https://doi.org/10.1175/1520-0450(1980)019<1254:TO ADAT>2.0.CO;2

Sheridan, P.J., Delene, D.J. and Ogren, J.A. (2001). Four years of continuous surface aerosol measurements from the Department of Energy's Atmospheric Radiation Measurement Program Southern Great Plains Cloud and Radiation Testbed site. J. Geophys. Res. 106: 2073520747. https://doi.org/10.1029/2001JD000785

Sherman, J.P., Sheridan, P.J., Ogren, J.A., Andrews, E., Hageman, D., Schmeisser, L., Jefferson, A. and Sharma, S. (2015). A multi-year study of lower tropospheric aerosol variability and systematic relationships from four
North American regions. Atmos. Chem. Phys. 15: $12487-$ 12517. https://doi.org/10.5194/acp-15-12487-2015

Takemura, T., Uno, I., Nakajima, T., Higurashi, A. and Sano, I. (2002). Modeling study of long-range transport of Asian dust and anthropogenic aerosols from East Asia. Geophys. Res. Lett. 29: 11-1-11-4. https://doi.org/10.10 29/2002GL016251

Toledano, C., Cachorro, V.E., Berjon, A., de Frutos, A.M., Sorribas, M., de la Morena, B.A. and Goloub, P. (2007). Aerosol optical depth and Ångström exponent climatology at El Arenosillo AERONET site (Huelva, Spain). Q. J. R. Meteorolog. Soc. 133: 795-807. https://doi.org/10.1002/ qj.54

Turkien, K.K., Nozaki, Y. and Benninger, L.K. (1977). Geochemistry of Atmospheric radon and radon products. Annu. Rev. Earth Planet. Sci. 5: 227-255. https://doi.org/ 10.1146/annurev.ea.05.050177.001303

Uno, I., Eguchi, K., Yumimoto, K., Takemura, T., Shimizu, A., Uematsu, M., Liu, Z., Wang, Z., Hara, Y. and Sugimoto, N. (2009). Asian dust transported one full circuit around the globe. Nat. Geosci. 2: 557-560. https://doi.org/10.10 38/ngeo583

van der Hulst, H.C. (1957). Light Scattering by Small Particles. John Wiley.

Wandinger, U., Müller, D., Böckmann, C., Althausen, D., Matthias, V., Bösenberg, J., Weiß, V., Fiebig, M., Wendisch, M., Stohl, A. and Ansmann, A. (2002). Optical and microphysical characterization of biomass-burning and industrial-pollution aerosols from multiwavelength lidar and aircraft measurements. J. Geophys. Res. 107: LAC 71-LAC 7-20. https://doi.org/10.1029/2000JD000202

Received for review, November 18, 2019 Revised, February 24, 2020 Accepted, April 3, 2020 